\title{
An Analysis of the 2013 National Budget Statement and Its Implications for Social Work Practise in Zimbabwe
}

\author{
${ }^{1}$ Edmos Mtetwa, ${ }^{2}$ Noel Muridzo \\ ${ }^{1}$ Lecturer, University Of Zimbabwe School Of Social Work Private Bag 66022 Kopje Harare \\ ${ }^{2}$ Part Time Lecturer University Of Zimbabwe School Of Social Work
}

\begin{abstract}
This paper reviews the 2013 National Budget for Zimbabwe that was presented in Parliament on 15 November 2012. The authors interrogate the extent to which the budget as a policy instrument fosters the developmental agenda. Selected key areas of human development are reviewed. Although estimates of expenditure are a reflection of the national economic policy direction, the current paper shall dwell much on the policy prescription of the budget in the light of scarce resources available in an economy still recovering from a decade of recession. The paper has selected such areas as public sector employment, health, social protection, and agriculture and food security. It is observed that the budget represents a splendid effort to realign the economy and equitably distribute the meager resources in an economy still recovering from a decade of recession.
\end{abstract}

\section{Introduction}

The role of the social work profession in the development of any society is beyond doubt. To this end, social workers have a critical duty to contribute to the development and improvement of social policy. This comes on the hills of the urgent need for the social work profession to adopt a proactive rather than reactive role in social intervention. It is from this conviction that this paper seeks to explore the implications of the 2013 national budget on the alleviation of social distress as well as the enhancement of social functioning in the country. In this light, the paper attempts to give an assessment of the extent to which the policy prescriptions contained in the 2013 National Budget Statement foster human development and welfare. Due to lack of space and scope, it is not possible to come up with a compendious analysis of the whole budget. However, a few budgetary items, deemed to be of immediate importance to the social work profession shall receive due attention.

\section{Zimbabwe's Economic Circumstances}

Zimbabwe experienced a fiscal crisis and decline in economic activity in all sectors of the

Economy post 2000 (Shamu, 2012). Hyperinflation, company closures and unemployment almost grounded all sectors of the economy to a standstill. During the past decade therefore the Zimbabwean economy has been mired in a severe vicious cycle of economic regression and paralysis (Chitambara, 2010: 3). From a peak of 9.7 percent in 1996 economic growth slumped to a record -14.8 percent in 2008(ibid). This economic regression and paralysis brought about increased poverty which in turn increased social and economic marginalisation and distress of already disadvantaged groups. By 2007, Zimbabwe's inflation had risen to a high figure of $3000 \%$ (Bird and Busse, 2007). By 2008, Zimbabwe's New Hyperinflation Index (HHIZ) estimated in mid-November 2008 that the country's monthly inflation rate was 79,600,000,000 percent which gives an equivalent daily inflation rate of 98.0 percent and the annualised inflation rate of 89.7 sextillion percent (Chitambara, 2010:4).

According to Kramarenko et al (2010) by the beginning of 2009, the exchange rate stood at $Z \$ 35$ quadrillion per US\$1).

The advent of the Government of National Unity in 2009 saw the resuscitation of the economy and with it, the social services such as education, health and social protection. It is here acknowledged that Zimbabwe's economic situation has not yet recuperated from the decade long recession that saw the inflation rising beyond unprecedented levels. As a sign of positive economic growth, Zimbabwe's real Gross Domestic Product (GDP) grew from 6\% in 2009 to 9\% in 2010. (International Monitory Fund, 2011). Year-on-year inflation stabilized after 2009 at around $4.5 \%$. The country's industrial capacity utilisation grew from $10 \%$ in 2008 to an average of 50\% in 2010 (Ministry of Finance, 2011). The removal of price and exchange rate distortions in both the labour and goods market supported a growth in household disposable incomes. With the growth in capacity utilisation and increased employment, the country's revenue mobilisation capacity increased from less than $10 \%$ in 2008 to $29 \%$ of GDP by 2010 (Shamu, 2012:2). The traditional revenue categories such as taxes on income and profits improved, although Value Added Tax (VAT) and Pay As You Earn (PAYE) remain the most important contributors to domestic revenue in the country (ibid). High unemployment levels 
(above 70\%) and low terms of domestic trade, however, have resulted in a very thin PAYE tax base, whose contribution is not sufficient to cover revenue for government obligations (ibid).

As a result, the provision of basic social services was affected negatively by the unstable political and economic environment. This was worsened in some years by unfavourable weather conditions such as droughts which saw the country becoming heavily dependent on humanitarian assistance from foreign donors for the provision of basic social services (Marisamhuka, 2010). Admittedly, there has been some noticeable improvement across all social service sectors since 2009. In this regard, government efforts to restore fiscal normalcy is analysed against two competing policy trajectories. First, the need to capitalize the service delivery machine by rekindling hopes in the bureaucracy as a way of bringing back the needed services. Secondly, the need to create enough fiscal space for the actual service delivery to the public by cutting expenditure on the administration and concentrating it more towards basic social services. Facing such a twin-track dilemma, the government, in the 2013 National Budget statement tried to take the so-called middle of the road approach.

\section{The Size Of The 2013 National Cake}

This paper takes due cogniscence of the fact that vanity of vanity is all vanity. One cannot expect miracles. To this end, the size of the national cake will always stand as a great obstacle to the realization of the values and aspirations of the social work profession. The 2013 National Budget Statement indicates that, an amount of US $\$ 3.8$ billion is anticipated in 2013, translating to $34.5 \%$ of GDP. Of the total revenues, recurrent expenditures are set at US\$3.3 billion (86.4\%), with only a balance of US\$500 million (13.6\%) left for the capital development budget. Given the central role of government in the provision of employment through capital projects such as the Public Sector investment programmes, any such shrinkage in capital investment is likely to compromise the ability of government to reduce unemployment. The size of the national cake therefore stands as a crucial imperator in the resource allocation matrices. Greeted with such a dilemma, any prudent fiscal policy must strive to grow the economy. Although social work has traditionally been classified as a consumptive profession, this paper would expect the 2013 budget to consolidate the earlier efforts to grow the economy for the benefit of the poor and marginalized members of society.

\section{Dispossible Income And Social Service Provision.}

The 2013 national budget statement talks of worrying statistics that in 2012 the government's wage bill gobbled about eight one percent of the total revenue, leaving nineteen percent as funds for other government services. This is against the international best practice of a wage bill consuming not more than thirty percent of the total revenue. Of prime concern to social workers is the level of employment costs in the recurrent Budget, accounting for a staggering $81 \%$ of the total current expenditures, while non-wage expenditures have been declining, accounting for the remaining 19\% of total current expenditures (2013 National Budget Statement). It is here contended that this state of affairs has the effect of crowding out other basic services such as education, child-welfare and health much to the detriment of the quest of the poor to salvage or ache some living. This compromise of social services delivery is a setback to the social Work profession whose sole mandate is that of striving towards universal provision of social services. It is however encouraging to note that even the government seems to be concerned about such a state of affairs hence all efforts are being made to rectify the anomaly. By 2013, employment costs are set to drop to 65 percent of the total revenue (about US\$2.6 billion). This is meant to account for a $65 \%$ share of the US\$3.8 billion total Budget.

In an attempt to further create fiscal space to accommodate other developmental projects as well as social services, the government envisages that this target is to gradually further reduce this share by 10 percentage points each year to reach $45 \%$ of the total Budget by 2015 and further to about $30 \%$ by 2016 . In an effort to maintain the wage bill at a reasonable level, government proposed to freeze all posts within the public service. "In order to gradually move towards the international best practice thresholds of 7\% of GDP and about $30 \%$ of the total Budget on the wage bill, Government will continue to maintain the freeze on recruitment, save for case by case special dispensations on critical areas. Furthermore, Government will also develop a remuneration framework that will guide the cost of living adjustment taking into account macro-economic fundamentals such as inflation and capacity of the economy" (2013 National Budget statement). This attempt to normalize the situation by keeping a freeze on the public service, though a prudent fiscal strategy is likely to adversely compromise service delivery in crucial respects. Given the low profile of social workers in Zimbabwe, the recruitment of the social workers in 2013 will be greatly compromised. This is because the Department of Social Services which is the largest employer of social workers will remain frozen. Traditionally, social workers have never been a priority in government. The prevailing situation has been that the government even saw it fit to replace them with para-professionals in times of scarcity. Priority has always been placed on teachers and the health personnel. This paper however, contends that the perpetuation of such a scenario is detrimental to service delivery, especially in the area of rendering services to the most vulnerable members of society such as children and persons with disabilities. (See table 1 below) 
Table 1: The Ratio Of Children To Social Workers In Selected Countries In Southern Africa

\begin{tabular}{|l|l|l|l|l|}
\hline COUNTRY & POPULATION & $\begin{array}{l}\text { POPULATION OF } \\
\text { CHILDREN }\end{array}$ & $\begin{array}{l}\text { TOTAL NUMBER } \\
\text { OF } \\
\text { WORKERS }\end{array}$ & $\begin{array}{l}\text { RATIO } \\
\text { SOCILDREN } \\
\text { SOCIAL WORKERS }\end{array}$ \\
\hline Botswana & 1,8 million & 784,000 & 420 & $1,867: 1$ \\
\hline Namibia & 2.0 million & 860,000 & 200 & $4,300: 1$ \\
\hline South Africa & 47 million & $15,000,000$ & 12,000 & $1,250: 1$ \\
\hline Zimbabwe & 12,5 million & $5,000,000$ & 118 & $42,373: 1$ \\
\hline
\end{tabular}

Source, Wyatt etal (2010) page 28.

The table above illustrates the fact that Zimbabwe's children are extremely exposed to especially difficult circumstances. The ratio of social workers to Zimbabwe's children looked at against the inelastic public service wage bill especially in the area of social welfare personnel paints a gloomy picture to the utility of the 2013 National Budget to proper social work practice.

Besides working with children, social workers also work with other vulnerable members of society such as persons with disabilities, the elderly, the unemployed as well as the less fortunate members of society.

Implicitly, the ratio of such other social groups to social workers is too large. According to a study conducted by the Zimbabwe Vulnerability Assessment Committee (2012) $\square$ 30\% of the sampled households had at least an orphan, $8 \%$ of the sampled households had a chronically ill member and $8 \%$ of the sampled households had a mentally or physically challenged member. The freeze of posts within the public service therefore needs to be sensitive and responsive to other priority areas such as service delivery in the needy areas. It is here contended that such areas should be broadened beyond the traditional education, health and security sectors to include social protection and welfare.

\section{Health}

According to the National Budget Statement, (2013: 128), the health sector was allocated an amount of 317 million dollars. This level of funding represents ten percent of total expenditure. This is just but two thirds of the expected health allocation recommended by the Abuja declaration of 15 percent. Given the size of the national cake and the attendant competing demands, this is a positive development. Even the budget statement acknowledges the role of donor agencies in the financing of health services. The budget however goes further to allocate an amount of 2 million towards the possible construction of provincial hospitals in Harare and Bulawayo. "Mr Speaker sir, work will commence towards feasibility studies for the construction of provincial hospitals in the case of Bulawayo and Harare" (National Budget Statement: 125). This sounds like an expansionary policy trajectory, largely informed by quantitative political overtures rather than a pragmatic policy meant at improving the quality of service delivery. The state of two major referral hospitals namely Harare central hospital and Impilo hospital still operate well below capacity. This paper therefore feels that in the interest of an efficient and effective health delivery system, resources should be concentrated primarily on the recapitalization and resuscitation of existing institutions rather than adding other white elephants.

\section{Social Protection.}

Social protection refers to policies and actions for the poor and vulnerable which enhance their capacity to cope with poverty, and equip them to better manage risks and shocks. Social protection includes a portfolio of instruments, including social cash transfers (Samson, 2009). The role of social protection to economic growth and development has received due emphasis from a number of scholars and institutions including the World Bank, United Nations Development Programmes among others. Adding its voice to the centrality of social protection, the Organisation for Economic Cooperation and Development (2009:17) asserts that: "poverty reduction depends on sustained and broad based growth, which in turn requires complementary initiatives that share economic benefits and promote better developmental outcomes for poor and excluded groups".

The active role played by social workers in championing and promoting social protection programmes therefore makes the profession an indispensable part of the development process. Social protection has therefore become an integral pillar of the social work profession. From the poor laws through to the Charity organization Society, the act of dispensing material resources has always been the sole foundation upon which the social work profession is anchored. This has seen the social work profession being synonymous with social welfare in lay parlance. This paper therefore will not have done justice to the topic at hand if it fails to give a scrutiny of the way social protection has been handled in the 2013 national budget. Although the government of Zimbabwe in its 2013 budget recognizes the importance of social protection to the wellbeing of the nation, it is here observed that more could still be done to improve service delivery in that respect. The shortage of social workers, coupled with financial constraints characteristic of a country emerging from a decade long economic and political quagmire have stifled progress in social protection provisioning. Of paramount significance to social work practice is the fact that an amount of 25,7 million has been allocated towards social protection in 
terms of the budget under discussion. This amount goes towards areas that include the Basic Education Assistance Module (BEAM) (15 million,) in the context of implementing the National Action Plan, targeting assistance to orphans, child headed families, the disabled, elderly and the chronically ill (page 126).

In any budget making process, it is common to believe that social protection is a drain to the economy given that it does not directly contribute any revenue to the fiscus. This paper however contends that a happy and socially secure nation is bound to be productive and prosperous.

The same sentiment has been echoed by Carlson (1999) who makes an observation that stable, sustainable economic development cannot be achieved unless and until social development also takes place.

Consequently, the social dimensions of economic development and productivity are as important as the economic dimensions. According to the Organisation for Economic Cooperation and Development (2009:1), social protection is an essential investment that contributes to economic growth and makes growth more propoor while directly reducing poverty. From a social work point of view, this paper argues that a sound fiscal policy framework coupled with a sustainable social protection policy is the way forward in a resource poor country like Zimbabwe. To this effect, measures must be put in place to rekindle and promote the traditional and self financing social protection programmes. These include the traditional food reserves commonly known as Isiphala Senkosi/Zunde Ramambo. Such endeavours are localized and more sustainable especially if given minimal support from the fiscus.

\section{Agriculture And Food Security}

It is here observed that the Social Work profession plays an active role in ensuring food security as a measure of securing social functioning. To this end, many such professionals are employed in humanitarian agencies such as the World Food Programme, Food and Agricultural Organisation among others where they are involved in the planning and execution of various food security programmes.

This paper is fully cogniscent of the fact that about seventy percent of Zimbabwe's population lives in rural areas where their source of livelihood is subsistence agriculture. According to the Zimbabwe Vulnerability Assessment Committee (2012) Zimbabwe's rural population thrives largely on subsistence agriculture with 80\% of peasants having cultivated maize (Zimbabwe's staple food crop). The same was reported in the 2011-2012 farming season where $79 \%$ of the population grew maize. Improving national food security therefore becomes a crucial policy trajectory geared towards the amelioration of the plight of the masses living and working in rural areas. Such an arrangement, if properly implemented usually results in rural development. "Mr Speaker Sir, it will be noted that with an overall proposed allocation of US\$159.4 million for agricultural development we are at $4 \%$ of the proposed 2013 Budget which regrettably is below the Maputo Declaration target of $10 \%$ ". In view of the population size found in Zimbabwe's rural areas wherein subsistence agriculture is the main form of livelihood, it is here felt that an amount of 159.4 million allocated for agriculture in 2013 is not sufficient. As per the observation above, the major determining factor in resourcing the budget is the size of the national cake.

In this light, a sound agricultural policy trajectory is the one that looks for synergies between government, the private sector and donor agencies. The 2013 budget statement has been prudent enough to rope in other players in the agricultural development of the nation. Sadly though, the 2013 National Budget Statement seems to take a commercial approach to agricultural financing much to the disadvantage of the poor rural peasants.

This paper therefore would like to note that in the absence of a comprehensive and sound policy framework, the demise of the agricultural sector shall continue to be imminent. This observation is also made by Anseeuw et al (2012) who contend that a combination of political and economic instability, exacerbated by poor domestic policies, contributed to the sustained underperformance of the agricultural sector. The period between 2000 and 2008 saw a steady decline in the production volumes of staple commodities and increasing reliance on food aid and imports from neighbouring countries.

Although government is making frantic efforts to rope in other players in an effort to augment the meager resources, such efforts need to pay due account of the fact that rural peasants find it difficult to embark on commercial agriculture. The current tumbling of cotton prices that has left many families in such places as Gokwe starving is a case in point. This paper therefore contends that whilst the provision of consumptive social services without an increase in resources towards productive sectors of the economy is likely to result in the promotion of dependency syndrome, the rural population still has a long way to go in their quest for food security. In Zimbabwe, given the prevailing socio-economic dynamic, it is pertinent to consider, especially in projects involving large amounts of state capital, whether a small farmer owes the duty to the state to be an efficient producer and accept the discipline which technology demands as much as the state owes a duty to him to get him out of poverty. 


\section{Livestock Production}

Any discussion of food security in rural Zimbabwe should take note of the fact that the main source of draft power is livestock. Drought power is made up of cattle and donkeys. A household of 5 requires about $740 \mathrm{~kg}$ of maize to satisfy its minimum energy requirements of $2100 \mathrm{kcal} /$ person/day (Zimbabwe Vulnerability Assessment Committee, 2012). The Zimbabwe Vulnerability Assessment Committee revealed that approximately $58 \%$ of the households sampled under the Zimbabwe Vulnerability Assessment Committee study of 2012 did not own cattle, $23 \%$ owned between 1 and 5 beasts whilst $19 \%$ owned more than five beasts. About $70 \%$ of the sampled households produced $100-200 \mathrm{~kg}$ of maize, only $3 \%$ of the households produced more than $800 \mathrm{~kg}$ of maize.

The importance of livestock to the rural subsistence agricultural sector should in no way be downplayed. As put forward by the Zimbabwe Vulnerability Assessment Committee (2012), about $70 \%$ of the sampled households who had less than one draught power animal produced less than $200 \mathrm{~kg}$ of cereals, while $41 \%$ of the households who possessed 6 or more draught power animals produced more than 1000kgs.

The 2013 national budget statement only allocated an amount of $\$ 10$ million to the livestock sector. In practical terms, only 3 million of that amount shall go towards the livestock loan scheme (see page 119 of the budget). This amount, although very insignificant given the extent to which the national herd had deteriorated over the years due to drought, inflation and other national challenges is a step towards the right direction. The only setback lies in the extent to which such a fund shall benefit more than seventy percent of peasants living and earning a living in the rural areas.

To this effect, government should encourage the donor community to participate in the restocking exercise, paying attention to the most impoverished members of society living in rural areas.

Most donor agencies have of late concentrated their efforts towards giving people small livestock such as goats and chicken. The current haphazard, unpredictable and unregulated efforts by these donor agencies fall far below national requirements. It is here observed that such livestock might not contribute much towards food security as they cannot be used as drought power.

\section{Irrigation Development}

On a positive note, within the limits of resources available to it, it is critical that government has realized the central role of irrigation development in drought mitigation in a situation where perennial droughts are now the order of the day. "Given the immense potential of irrigation in improving agriculture production, support amounting to US\$3.5 million was extended in 2012 and this will be further topped up in 2013 as part of upgrading and expanding our irrigation development programme" (2013 National Budget Statement: 121). Such a realization on the part of government gives the budget a human face.

\section{Financing Agriculture}

According to the 2013 National Budget Statement, agriculture shall be financed mainly by the private sector with little government intervention outside the policy and regulatory functions. The Agricultural Bank of Zimbabwe and other larger insurance firms are poised to play an instrumental role in financing agriculture.

While this sounds more sustainable in the long-run, if not well policed, this has the effect of placing farming inputs beyond the reach of the rural poor. More so, it is worth of note that the Agricultural Bank of Zimbabwe is grossly incapacitated and not financially sounds. In the rural areas, availability of banking facilities remains a challenge. Agribank, a government-owned commercial bank specifically created for agricultural finance, was formed from the dissolution of the Agricultural Finance Corporation in 1996. However, it only began operating in 2000 , at the time the government was increasingly cash-strapped. As a result, the Agribank has never been able to meet its mandate fully, as it mainly assisted in the distribution of central bank project funds (Anseeuw et al, 2012). Farmers thus had no alternative but to approach commercial banks (17 commercial banks with a combined asset base of US\$516 million) for finance. However, the formal banking sector has been reluctant to service the agricultural sector, owing to a number of factors, particularly land insecurity. The commercial banks held that the nationalisation of land under the land redistribution programme has rendered land a 'dead' asset, which cannot be used as collateral for agricultural loan applications. In its November 2005 report to Parliament, the Portfolio Committee on Lands, Land Reform, Resettlement and Agriculture said that it was 'concerned to note that the current financing facilities are tailormade for large-scale commercial farmers at the expense of smallholders'. So officially, there is a policy on agriculture finance, but it is not being implemented. In terms of inputs, it is worth noting that fertilizer companies are also struggling. It is here contended that commercial agriculture usually thrives on the availability of collateral security. The tenurial system of subsistence farmers in rural areas of Zimbabwe is communal and cannot be used for the securing of a bank loan. On a positive note, the 2013 national budget statement does acknowledge the dilemma encountered by the new commercial farmers whose land cannot attract funding. Unfortunately, the same statement still talks of 99 year leases without a coherent approach to 
making them commercially viable. In the interest of food security and the general enhancement of agricultural productivity in Zimbabwe, this paper would go for the shift in policy towards the issuance of title deeds to tenants after a comprehensive and objective land audit. Such a policy option would go a long way in recapitalizing and resuscitating agriculture.

\section{Support Towards The Vulnerable And Disadvantaged Households}

In keeping with the spirit of developmental social work, the budget has made provisions for the acquisition of inputs for the vulnerable households. In this light, this signals a departure from a remedial and piecemeal approach to poverty alleviation towards a more developmental and sustainable social assistance framework. The cooperating partners' contribution of US\$19.3 million is set to benefit a total of 77800 disadvantaged households in 24 districts. Each household is entitled to an input package costing US\$160 for which the farmer is required to contribute US\$32 with the donor providing the balance of US\$128. With respect to the Government component, the support targets to assist 60000 vulnerable households with a free input hand package comprising $1 \times 10 \mathrm{kgs}$ maize or $1 \times 5 \mathrm{kgs}$ of small grain seed, $1 \times 50 \mathrm{kgs}$ of compound D and $1 \times 50 \mathrm{kgs}$ of Ammonium Nitrate (op cit: 120). It is however, observed that the sixty thousand households targeted are just but a drop in the ocean given that at least seventy percent of Zimbabweans live below the Poverty Datum line (Poverty Assessment Study Survey of 2003).

In conclusion, the 2013 National Budget Statement represents a major milestone towards economic recovery and the revitalization of social services in a country that had witnessed a rapid plumation in all development indicators. The freeze on public service employment is likely to stifle progress in the areas of social protection since donor agencies are not prepared to fund administrative costs. The budget has a proper focus towards the health delivery system. The only handicap lies in government's obsession towards the expansionary thrust usually at the expense of quality of service. Social protection programmes are yet to recover from a decade long recession, with only educational assistance having taken off. The other programmes namely social assistance or social cash transfers are still erratic. Agriculture on the other hand is poised to benefit immensely from the policy proposals. The political lock jam surrounding agriculture should however be removed if sustainable food security is to be achieved. On the whole, the 2013 Budget Statement stands as a true reflection of the economy on a recovery path.

\section{References}

[1]. Anseeuw, W. Kapuya T. and Saruchera D. (2012) Zimbabwe's agricultural reconstruction:

[2]. Present state, ongoing projects and prospects for reinvestment. Planning Division Working Paper Series No. 32 Development Bank of Southern Africa.

[3]. Carlson, B. (1999) social dimensions of economic development and productivity: inequality and social performance. London: The Organisation for Economic Cooperation and Development

[4]. Chitambara P. (2010) Social Protection in Zimbabwe, Labour and Economic Development Research Institute of Zimbabwe (LEDRIZ): Harare

[5]. Government of Zimbabwe (2012) 2013 The National Budget Statement. Presented to the Parliament of Zimbabwe on Thursday, November 15, 2012. Harare, Ministry of Finance.

[6]. Government of Zimbabwe (2006) Zimbabwe 2003 Poverty Assessment Study Survey Main Report. Harare, Ministry of Public Service, Labour and Social Welfare.

[7]. International Monetary Fund (2011) 'Country Report Number 11/135; Zimbabwe 2011 Article IV Consultation, 'Publication Services: Washington, DC.

[8]. Kramarenko V, Engstrom L, Verdier G, Fernandez G, Oppers S. E., Hughes R, McHugh J, Coats W. (2010)

[9]. Zimbabwe: Challenges and Policy Options after hyperinflation. Washington D.C, International Monetary Fund.

[10]. Marisamhuka L. (2010) Zimbabwe Country Analysis Report for Zimbabwe. Government of Zimbabwe/ United Nations Country Team. Harare.

[11]. Ministry of Finance (2009-2012) 'Budget and expenditure statements, 2009-2012,' Government Printers: Harare.

[12]. OECD, (2009) Social Protection, Poverty Reduction and Pro-Poor Growth. POLICY GUIDANCE NOTE

[13]. London: The Organisation for Economic Cooperation and Development Samson M (2009) Cash Transfers and Pro-Poor Growth: Promoting Pro-Poor Growth. London, Organisation for Economic Co-operation and Development.

[14]. Shamu S (2012) 'Resource Mobilisation for Health under the Zimbabwe Investment Case 2010-2012,' EQUINET Discussion Paper Series 94. Training and Research Support Centre, EQUINET: Harare.

[15]. Wyatt A, Mupedziswa R, and Rayment C (2010) Institutional Capacity Assessment. Harare, Department of Social Services, Ministry of Labour and Social Services.

[16]. Zimbabwe Vulnerability Assessment Committee (Zim Vac) (2012) Rural livelihoods Assessment May 2012 Report. Harare, Food and Nutrition Council. 